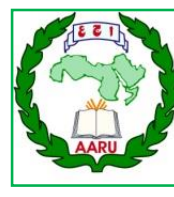

Arab Univ. J. Agric. Sci., Ain Shams Univ., Cairo, Egypt

29(2), 627-643, 2021

Website: http://ajs.journals.ekb.eg

DOI: 10.21608/ajs.2021.53764.1310

\title{
Using In Vitro Technique to Evaluation Adding Nano Cobalt to Some Roughages
}

\author{
Shymaa M Abd El-all ${ }^{*}$, Etab RI Abd El-Galil, Hamdy M Mosa \\ Animal Production Dept, Faculty of Agriculture, Ain Shams University, P.O. Box 68, \\ Hadayek Shoubra11241, Cairo, Egypt \\ *Corresponding author: shymaamojahed@gmail.com
}

Received 24 February, 2021

Accepted 5 June, 2021

\begin{abstract}
This paper is evaluating the addition of nanocobalt on dry matter, organic matter, cellulose and hemicellulose degradability of $I n$ vitro gases technique. Nanocobalt as an additive were used as $0,25,50,75,100$ and $125 \%$ from the animal requirements on DM basis. The regular ration (1:1 concentrate: clover hay) was incubated for 24 hours. Then 24 and 48 hours of dry matter, organic matter, cellulose and hemicellulose were used to research the impact of adding 25 and 50\% nanocobalt to some roughages (rice, bean, wheat, bagasse and peanut) straws using In-vitro disappearance. Results of In-vitro gas indicated that the DMD degradability values were increased $(\mathrm{P}<0.05)$ in 50 and $75 \%$, while the highest of OMD was in 25 and $50 \%$ of nanocobalt. The nanocobalt had no effect on $\mathrm{pH}$, but had a greater influence on the values of ammonia and TVF's, as well as the degradability of cell wall components with microbial proteins. In control ration, the gas production was high, adding cobalt $(100 \%)$ and nanocobalt (25 and $50 \%)$ than other of addition. High values of microbial protein (MP) and microbial protein efficiency (EMP) recorded for all different nanocobalt added. Nanocobalt $25 \%$ output gas of DM, NDF, ADF, cellulose and hemicellulose showed increase $(\mathrm{P}<0.05)$ compared to any additional levels. It concluded that the addition of nanocobalt increased the production
\end{abstract}

of gas, ammonia, TVF's, metabolizable energy and degradability of cell wall constituents. It showed that the addition of nanocobalt had a stronger effect on disappearance of all roughages as $\mathrm{DM}, \mathrm{OM}, \mathrm{NDF}, \mathrm{ADF}$, cellulose and hemicellulose. Furthermore, the addition of $25 \%$ nanocobalt had a significant effect $(\mathrm{P}<0.05)$ on improving In-vitro $\mathrm{DM}$ and $\mathrm{OM}$ disappearance of all roughages except bagasse had a significant effect in add $50 \%$ nanocobalt.

Keywords: In-vitro gas production, Nanocobalt, Dry matter, Cellulose, Hemicellulose, Roughages

\section{Introduction}

High biomass, low crude protein content of about 3 to 4 percent and high crude fiber content of about 35 to 48 percent overall are several by-products of the human food industry (Devendra 1997). Typical food for ruminants is in many developing countries, such as fibrous crop residues, such as cereal straws, sugarcane tops, pelts, cocoa pod husks, pineapple waste, etc. Ruminal microflora can synthesize vitamin B12 if adequate amounts of cobalt are available in the diet. As a result, dietary cobalt may be protected by these species' requirement for vitamin B12. However, the proposed replacement of cobalt with vitamin B12 does not provide enough evidence to evaluate, under 
field conditions, the health and efficiency consequences for certain species. Ruminal microflora can also affect the supplementation of cobalt from the diet, its structure and function. Any of the minor beneficial effects observed in ruminants after the supply of cobalt are likely to be correlated with an unspecific effect of cobalt on the microflora, not with vitamin B12. Cobalt must also provide ruminants with the ideal supply of micronutrients (Sutton and Elliot 1972). Increasing the production of ruminal propionate in beef steers by adding additional cobalt to a highly concentrated cobalt deficiency diet (Tiffany et al 2006 and 2002). Gall et al (1949) indicated that the digestibility of a diet decreases through bacterial modifications when cobalt is deficient. Although, the mechanism of action is not clear, (Scholljegerdes et al 2010) found that the intake of forage in lambs was increased by dietary cobalt. Improvements in ruminal fermentation associated with improvements in the population of ruminal microbes, specifically cellulolytic bacteria, which tend to be most vulnerable to additional cobalt, may have contributed to an increase in intake. Therefore, to more thoroughly assess the effect of cobalt super nutritional levels in rising lambs, a digestion and growth efficiency trial site and scope is warranted. In the processing of nanoparticles, nanotechnology can be used both as novel food ingredients or additives and to enhance food safety and quality control in order to improve digestion and absorption in livestock. Nanotechnology is continuously evolving and its applications are increasingly diverse and special, with a high potential for improving livestock and animal performance in general, (Bunglavan et al 2014). Studies of nanotechnology in these areas are still very small. In animal nutrition research, the use of nanoparticles that can significantly improve the efficiency of livestock growth and development should be pursued at a lower cost to consumers. A great deal of research, however, is still required to promote the effectiveness and safety of nanotechnology and to avoid harm to animals, the environment and human beings. Results from (Etab and El-Bordeny 2018) showed that added nanocobalt impacts on cellulolytic bacteria growth and increases cellulose, ammonia, total volatile fatty acids, metabolisable energy and degradability of cell wall constituents. Therefore, further investigations are required to determine the effect of nanomineral supplements on improved in-vitro gas output and in-vitro degradability. The rate and level of DM fermentation in rumen is a very important determinant for the nutrients consumed by ruminants. The In vitro gas production technique (Menke and Steingass 1988) has been developed to estimate the nutritional value of drillings and estimate the rate and degree of DM degradation through the use of gas production indirectly during fermentation. Animal intake (Orskov 1989), food consumption (Blummel and Orskov 1993), synthesis of microbial protein (Krishnamoorthy et al 1991, Krishnamoorthy et al 2005) and in vivo digestibility are well-defined in the field of in vitro gas processing (Khazaal et al 1993). Since it is simple to use and able to process a large number of samples in a short time, it is important to find significant information because of the benefits of gas processing technology (Valentin et al 1999). Several authors researched in vitro gas processing techniques in fermentation kinetics (Cone et al 1998, 1999 and 2002). The principal goals of the current study are to determine the optimal nanocobalt level added to the decay of in vitro gas output and the degradability of in vitro rice straws, bean straw, wheat straw, bagasse and peanut straw added to the disappearance of in vitro.

\section{Materials and Methods}

\subsection{The first experiment: In vitro gas pro- duction technique}

For each point, a total weight of $400 \pm 4 \mathrm{mg}$ was weighed in $125 \mathrm{~mL}$ glass bottles two days before beginning of the experiment (containing clover foin as a rugging and concentrate at a ratio of 50:50. A buffer solution was prepared and flushed continuously with $\mathrm{CO} 2$ at 39 $\mathrm{C}$ before adding rumen fluid as illustrated by Szumacher-Strabel et al (2002) during sample inoculation. Rumen fluid has been obtained 


\section{Using In Vitro Technique to Evaluation Adding Nano Cobalt to Some Roughages}

from the slaughter house and the buffalo. The rumen fluid collected was mixed in a (1-1) container and transported into a laboratory at $39^{\circ} \mathrm{C}$ with an $\mathrm{O}_{2}$-free headspace. The rumen fluid was filtered into four layers of cheesecloth upon arrival at the laboratory to remove large particles. The solution was used to buffer the bottle with a ratio of $4: 1$ for the rumen fluid, and $40 \mathrm{~mL}$ of this inoculum was applied to every bottle. The original $\mathrm{pH}$ of the inoculum was 6.8 to 6.9. In two different runs, triplicates of each sample were used.

\subsubsection{Degradability}

A degradability of the dry matter was measured as the difference between the DM of the sample and the residual after $48 \mathrm{~h}$ in incubation/DM in the sample*100 (percent dDM). The same approach for evaluating feed ingredients was employed to determine the NDF and ADF of the residuals after fermentation. An incubation, ADF, cellulose and hemicellulose degradability were measured for the difference between the sample material before and after the incubation, / sample before incubation* 100 .

\subsubsection{Total gas production}

After 24 hours of sample incubation, a replacement of the syringe piston connected to the serum flasks estimated the total gas output (TGP). In vessels which have the fluid and substratum of the tamped rumen, the gas generated in white vessels, the gas produced by fermentation was determined by subtracting the total gas produced from it (without substrate).

\subsubsection{Calculation}

Digestibility of organic matter in vitro (OMD, g/kg OM), measurements of shortchain fatty acid (SCFA) according to the levels of (Getachew et al 2002), performance of microbial biomass (MCP) and efficiency of development of microbial biomass (EMP), were carried out according to Blummel et al (1997):

$\mathrm{ME}(\mathrm{mJ} / \mathrm{kg} \mathrm{DM})=2.20+0.136 \mathrm{GP}+0.057 \mathrm{CP}$

(\%) ................................... (1) $\mathrm{OMD}=14.88+0.889 \mathrm{GP}+4.5 \mathrm{CP}(\%)+$ 0.0651 ash $(\%)$........................... (2) SCFA $(\mathrm{mmol} / 200 \mathrm{mg} \mathrm{DM})=-0.00425+$ $0.0222 *$ GP ........................... (3)

$\mathrm{MCP}(\mathrm{mg} / \mathrm{g} \mathrm{DM})=\mathrm{mg}$ dDM $-\mathrm{GP} * 2.2 \ldots \ldots$ (4)

$\mathrm{EMP}=(\mathrm{mg} \mathrm{dDM}-\mathrm{GP} * 2.2)) / \mathrm{mg} \mathrm{DMD}$..... (5) Where: GP, after 24 hours of incubation, is the net gas production of $200 \mathrm{mg}$ of dry sample in $\mathrm{mL} ; 2.2 \mathrm{mg} / \mathrm{mL}$ is the factor stoichiometric that shows $\mathrm{C}, \mathrm{H}$, and $\mathrm{O}$ for $1 \mathrm{~mL}$ of gas generated by the SCFA gas.

The filtered rumen liquor was subjected to further research for each sample after 48 hours of incubation. The $\mathrm{pH}$ of the rumen fluid was calculation by the $\mathrm{pH}$ meter and the ammonia concentration quantitative analysis was performed using the Nesler method updated by (Szumacher-Strabel et al 2002, Barnett and Reid 1956) analyzed total volatile fatty acids "TVFA's".

\subsubsection{Chemical analysis of feed ingredients}

$\mathrm{DM}$ and ash, crude fiber (CF), crude protein $(\mathrm{CP}=$ nitrogen percentage $\times 6.25)$, and ether extract (EE) were analyzed according to ingredient ration (AOAC 1997). The NDF and Ankom200 fiber analyzers were used to sequentially analyze the content of neutral detergent (NDF), acid detergent fiber (ADF) and acid detergent lignin (ADL) (Van Soest et al 1991) with 72 percent sulfuric acid subsequently absorbed for 3 hours The NDF content in the neutral detergent solution was analyzed using two heat stable alpha-amylase additions and one g sodium sulfite per gm sample (Hansen et al 2016). It expresses both NDF and ADF as well as cellulose, including ash residual and hemicellulose measured in NDF and ADF values. A distinction was taken from the nitrogen-free extract (NFE). 


\subsubsection{Standard ration and nanocobalt addi- tion}

Six quantities of nanocobalt have been calculated in a daily ration. Nanocobalt levels of $0.25,50,75,100$ and 125 percent of small ruminants (sheep and goats) $(0.2 \mathrm{mg} / \mathrm{kg}$ DM intake $=100$ percent $)$ and 100 percent cobalt supplemented the ration as a standard level, according to (NRC 1985) requirements. Each of the six levels was diluted into $100 \mathrm{ml}$ of distilled water and then added to the checked glass vessels. A mixture of concentrates (corn grain, wheat bran, soy meal, salt, and lime) and Egyptian clover hay was used to test the ration. To prepare the ration, the $1: 1(\mathrm{w} / \mathrm{w})$ roughage to concentrate ratio was used. The chemical compositions of feedstuffs are mentioned in Table 1.

\subsubsection{Nanocobalt characterization}

Thermal breakdown of cobalt hydroxide synthesized with cobalt acetate, ammonium hydroxide, and 10 percent glycerol, cobalt oxide nanoparticles have active in preparation (Manigandan et al 2013). Calcined at $450^{\circ} \mathrm{C}$, cobalt oxide nanoparticles' $\mathrm{X}$ ray determined (XRD) patterns show the cubic phase structure of the cobalt oxide. Using the Scherrer ratio, the average cobalt oxide grain size is estimated and has been found to be around $49 \mathrm{~nm}$. It can be seen that particles adopt irregular morphologies of different particle sizes. Furthermore, cobalt oxide nanoparticles show a rod shape with a smooth base. It clearly shows the fine rod, because of the aggregation, as particles adsorbed on the surface. This indicates that the rod was exclusively due to magnetic induction as agglomerates between the particles (Koutzarova et al 2006).

\subsection{The second experiment: In vitro disap- pearance}

The disappearance of dry matter, organic matter, NDF, ADF, cellulose and hemicellulose in vitro has been measured using the (Terry et al process 1969). Two tubes were used as replicates of each sample at varying incubation times $(24,48 \mathrm{hrs})$.

\subsubsection{Roughages}

Five roughages of cellulolytic material were ready for in vitro disappearance to be tested. The roughage is as follows: 1- Rice straw. 2- Stroke of wheat 3- Bagasse 4- Stroke of beans. 5- Straw of peanuts. In the table, the chemical compositions of five roughages are shown Table 2.

\subsubsection{Statistical analysis}

Statistically, in conjunction with user guide method of statistical analysis was analyzed in vitro gas production degradability, dry substances, organic matter, hemicellulose and cellulose digestibility (SAS 1998). The multiple test Duncan was used to separate between means (Duncan 1955). The following model was used:

$$
Y_{i j}=\mu+S_{i}+e_{i j}
$$

Where: $\mathrm{Y} i \mathrm{j}=$ observation of a studied trait, $\mu$ $=$ General mean common element to all observation, $\mathrm{Si}=$ effect of $\mathrm{i}^{\text {th }}$ treatment $(\mathrm{i}=1 \ldots 6)$, and $\mathrm{e} i \mathrm{j}=$ effect of experimental error of $\mathrm{j}^{\text {th }}$ observation for $\mathrm{i}^{\text {th }}$ treatment. 
Using In Vitro Technique to Evaluation Adding Nano Cobalt to Some Roughages

Table 1. Standard ration chemical composition and cell wall constituents

\begin{tabular}{|l|l|l|l|}
\hline Item & Hay of clover & Concentrate & $\begin{array}{l}\text { Standard } \\
\text { ration }\end{array}$ \\
\hline Dry matter & 92.40 & 87.05 & 89.73 \\
\hline Organic matter & 86.79 & 94.73 & 90.76 \\
\hline Crud protien & 17.41 & 16.19 & 16.80 \\
\hline Ether extract & 3.98 & 4.77 & 4.38 \\
\hline Crud fiber & 40.94 & 20.67 & 30.80 \\
\hline Non-Fiber Carbohydrate (NFC) & 24.46 & 53.10 & 38.78 \\
\hline Ash & 13.21 & 3.17 & 9.24 \\
\hline Cell wall constitutes & & & \\
\hline NDF & 40.94 & 20.66 & 30.80 \\
\hline ADF & 26.88 & 53.94 & 16.14 \\
\hline ADL & 5.80 & 1.41 & 3.61 \\
\hline Hemicell. & 14.66 & 15.24 & 14.06 \\
\hline Cellulose & 12.53 & 3.98 & 21.08 \\
\hline
\end{tabular}

Concentrate: $1 \%$ lime stone, $0.8 \%$ salt $(\mathrm{NaCl}), 20 \%$ Wheat bran , $22 \%$ Soybean meal 55.9\% Corn grain . ND: Non Detected - Non-Fiber Carbohydrate (NFC)

Table 2. Chemical composition of five studied roughages

\begin{tabular}{|l|c|c|c|c|c|}
\hline Item & Rice straw & Wheat straw & Bagasse & Bean straw & Peanut straw \\
\hline Dry matter & 89.00 & 93.11 & 92.05 & 91.68 & 89.80 \\
\hline On dry matter \% & \multicolumn{5}{|l|}{} \\
\hline Organic matter & 85.56 & 82.36 & 98.90 & 66.27 & 93.20 \\
\hline Crud protien & 1.92 & 4.48 & 1.74 & 5.67 & 12.40 \\
\hline Ether extract & 2.24 & 1.02 & 2.00 & 1.26 & 4.00 \\
\hline Crud fiber & 45.09 & 46.99 & 41.90 & 47.53 & 37.30 \\
\hline Non-Fiber Carbohydrate (NFC) & 36.31 & 29.87 & 53.29 & 33.73 & 39.50 \\
\hline Ash & 14.44 & 17.64 & 1.08 & 11.81 & 6.80 \\
\hline Cell wall constitutes & 79.09 & 80.40 & 80.33 & 48.50 & 62.00 \\
\hline NDF & 48.28 & 48.52 & 61.51 & 20.40 & 50.00 \\
\hline ADF & 10.55 & 10.30 & 19.60 & 4.30 & 10.90 \\
\hline ADL & 30.81 & 31.88 & 18.80 & 28.10 & 12.00 \\
\hline Hemicell. & 37.73 & 38.22 & 41.90 & 16.10 & 39.10 \\
\hline Cellulose
\end{tabular}

NDF: Neutral detergent fiber, ADF: Acid-Detergent fiber, ADL: Acid-Detergent Lignin

The following statistical model used for in vitro dry matter, organic matter, hemicellulose, and cellulose degradation:

$$
\mathrm{Y}_{\mathrm{ij}}=\mu+\mathrm{S}_{\mathrm{i}}+\mathrm{T}_{\mathrm{k}}+\mathrm{e}_{\mathrm{ijk}}
$$

Where: $\mathrm{Y} i \mathrm{j}=$ observation of a studied trait, $\mu$ $=$ General mean common element to all observation, $\mathrm{Si}=$ effect of $\mathrm{i}^{\text {th }}$ treatment $(\mathrm{i}=1,2), \mathrm{T}_{\mathrm{k}}$ $=$ effect of $\mathrm{k}^{\text {th }}$ treatment $(\mathrm{k}=1,2 .$. and 3$)$ and $\mathrm{e}_{\mathrm{ij}}$ $=$ effect of experimental error.

\section{Results and Discussion}

\subsection{The first experiment: In vitro gas pro- duction}

\subsubsection{Degradability}

After 24 hours, a significant increase $(\mathrm{P}<0.05)$ in DM degradability was reported for nanocobalt supplemented rations (50 and 75 percent), while maximum DM degradability was reported for rations supplemented with 25 
and 50 percent of the cobalt requirement, respectively (Table 3). A major impact of supplementation with cobalt nanoparticles (25 and 50 percent) on $\mathrm{OM}$ degradability has been shown in current studies. By comparison, (Partha Sarathi Swain et al 2015) stated that nanoparticles in minerals had a significant potential, even at very less than traditional organic and inorganic sources as mineral feed supplements in animals. However, systemic and extensive studies should be carried out over a long period of time to assess the toxic effects, if any, following animal feeding. In order to normalize the positive and harmful effects of these synthesized mineral nanoparticles, they must also be fed to a large number of animals before they routinely are inserted into the ration. Levels of cobalt nanoparticles above $50 \%$ of cobalt requirements led to a significant decrease in the degradability of $\mathrm{OM}(\mathrm{P}<0.05)$ (Table 3). On the other hand, the supplementation of cobalt nanoparticles had a big impact on NDF, ADF, and cellulose degradation within 24 hours, with $100 \%$ and $125 \%$ exception. In addition, cobalt nanoparticles supplementation (75 percent) recorded higher hemicellulose degradation compared to control ration (0 percent level) and cobalt oxide supplement ration compared to control ration ( 0 percent level) (100 percent). This positive response to cobalt nanoparticles' NDF, ADF and cellulose degradability and cobalt supplementation may be attributable to the fact that cobalt nanoparticles resulted in a 25 percent degradability improvement compared to the control ration (Table 3). In this context, due to enhance species of cellulolytic digesters, (Elghandour et al 2014) documented improveing degradability of fiber fractions Fibrobacter succinogenes, Ruminococcus flavifaciens and $\mathrm{Se}$ lenomonas ruminantium. (Colombatto et al 2007 ) verified the increase in cellulose and $x y-$ lene fermentation by the combination of preand post-incubation action, increasing cellulolytic enzyme activity (Colombatto et al 2007).

\subsubsection{Fermentation parameters}

The addition to the experimental ration of ascending cobalt nanoparticles had no major effect on the $\mathrm{pH}$ value and the ME metabolizable energy (Mcal/g) (Table 4). Significant increases in the concentration of ammonia $(\mathrm{mg} / 100 \mathrm{ml})$ and TVFA'S (meq/100 $\mathrm{ml})(\mathrm{P}>$ 0.05 ) have been observed, resulting in a 25,50 and 75 percent increase compared to other levels in the cobalt nanoparticles supplant ration. The further effects of nanocobalt on bacterial development, which has increased ruminal bacterial growth and activities and increased protein degradation, are due to these findings (Table 4). The ruminant ration supplemented with cobalt nanoparticles resulted in an improvement of 125 percent of the requirements in microbial mass protein (MP) and microbial mass efficiency (EMP) compared to the control (0 percent supplemented) and ration supplemented with cobalt oxide. Ruminal $\mathrm{pH}$ during the experimental fermentation processes was not impaired. Several studies have shown that $\mathrm{pH}$ is relatively stable during fermentation because of the growing use of $\mathrm{pHs}$ and lactates and satisfies the requirements for the operation of rumen microbes (Elghandour et al 2014). The development of gas that is a substratum mainly depends on the availability of rumen microorganisms in nutrients (Elghandour et al 2014, Kholif et al 2014). Rumen gases are formed by the fermentation of acetate, propionate and butyrate into dietary carbohydrates. The regular ration of various additives, however, had the same fibre fraction content in the current studyIt is thus clear that ammonia innovations in the rumen (Hristov et al 2013) are increased by microbial species, by enhancing protein degradation and increasing the animal's total $\mathrm{N}$ excretion. Compared to high nanocobalt levels, the low level of nanocobalt used (25 and 50) in this study improved degradability, gas output and fermentation kinetics (SCFA, NH3 and MP). The ration has been observed for enhanced ME, MP and GP 24. High 

to Some Roughages

Table 3. Digestibility after 24 hours of DM, OM, cellulose and hemicellulose with basic DM

\begin{tabular}{|c|c|c|c|c|c|c|c|c|c|c|c|c|}
\hline Item & control & Norma & & & & & & & Nano. & & & SE \\
\hline Cobalt level & 0 & 25 & 50 & 75 & 100 & 125 & 25 & 50 & 75 & 100 & 125 & \pm \\
\hline DMD $\%$ & $60.31^{\mathrm{d}}$ & $66.36^{\mathrm{a}}$ & $64.85^{\mathrm{b}}$ & $64.62^{\mathrm{b}}$ & $64.63^{b}$ & $61.98^{\mathrm{c}}$ & $59.96^{\mathrm{d}}$ & $62.78^{c}$ & $61.75^{\mathrm{c}}$ & $54.40^{\mathrm{e}}$ & $60.84^{\mathrm{d}}$ & 0.70 \\
\hline OMI & $31.78^{\mathrm{a}}$ & $31.36^{\mathrm{a}}$ & $31.82^{\mathrm{a}}$ & $31.13^{\mathrm{a}}$ & $31.26^{\mathrm{a}}$ & $30.10^{\mathrm{a}}$ & $30.07^{\mathrm{a}}$ & $30.16^{\mathrm{a}}$ & $28.22^{b}$ & $27.12^{c}$ & $29.48^{b}$ & 0.27 \\
\hline $\mathrm{NDF}$ & $29.84^{\mathrm{d}}$ & $43.83^{\mathrm{a}}$ & $40.64^{\mathrm{b}}$ & $38.27^{c}$ & $40.60^{\mathrm{b}}$ & $33.65^{\mathrm{cd}}$ & $30.76^{\mathrm{d}}$ & $34.84^{\mathrm{cd}}$ & $35.62^{\text {cd }}$ & $40.54^{\mathrm{b}}$ & $41.33^{\mathrm{ab}}$ & 0.95 \\
\hline ADFI & $22.29^{\mathrm{e}}$ & $43.12^{\mathrm{b}}$ & $39.39^{\mathrm{bc}}$ & $35.48^{\mathrm{c}}$ & $35.73^{\mathrm{c}}$ & $30.12^{\mathrm{de}}$ & $27.38^{\mathrm{de}}$ & $32.88^{\mathrm{de}}$ & $29.38^{\mathrm{de}}$ & $49.46^{\mathrm{a}}$ & $47.37^{\mathrm{ab}}$ & 1.65 \\
\hline Hemi D, \% & $38.19^{b}$ & $44.58^{\mathrm{a}}$ & $42.01^{\mathrm{ab}}$ & $41.32^{\mathrm{ab}}$ & $45.96^{\mathrm{a}}$ & $37.55^{\mathrm{b}}$ & $34.45^{\mathrm{c}}$ & $37.01^{\mathrm{b}}$ & $42.50^{\mathrm{ab}}$ & $30.50^{\mathrm{d}}$ & $34.70^{\mathrm{c}}$ & 0.99 \\
\hline Cellul D, \% & $32.91^{\text {ed }}$ & $33.19^{\text {ed }}$ & $35.61^{\mathrm{d}}$ & $31.35^{\mathrm{e}}$ & $30.05^{\mathrm{e}}$ & $30.87^{\mathrm{e}}$ & $45.36^{\mathrm{c}}$ & $44.05^{\mathrm{c}}$ & $46.72^{\mathrm{b}}$ & $51.37^{\mathrm{a}}$ & $49.72^{b}$ & 3.21 \\
\hline
\end{tabular}

DMD: Dry Matter Digestibility, OMD: Organic Matter Digestibility, NDFD: Neutral detergent fiber Digestibility, ADFD: Acid-Detergent fiber Digestibility

Table 4. Gas value (gas output kinetics in ration $\mathrm{ml} / 400 \mathrm{mg} \mathrm{DM}$ )

\begin{tabular}{|c|c|c|c|c|c|c|c|c|c|c|c|c|}
\hline Item & Contro & & & Normal & & & & & Nano. & & & SE \\
\hline cobalt Level & $\mathbf{0}$ & 25 & 50 & 75 & 100 & 125 & 25 & 50 & 75 & 100 & 125 & \pm \\
\hline \multicolumn{13}{|c|}{ Gas production } \\
\hline GP24 & $63.00^{\mathrm{a}}$ & $62.33^{\mathrm{a}}$ & $63.50^{\mathrm{a}}$ & $61.50^{\mathrm{b}}$ & $62.00^{\mathrm{a}}$ & $58.75^{\mathrm{c}}$ & $59.50^{\mathrm{b}}$ & $60.00^{b}$ & $54.50^{\mathrm{d}}$ & $52.00^{\mathrm{d}}$ & $53.00^{\mathrm{d}}$ & 0.85 \\
\hline $\begin{array}{l}\text { GP/hr } \\
\text { first } 24\end{array}$ & 6.00 & 5.90 & 6.01 & 5.85 & 5.88 & 5.61 & 5.60 & 5.62 & 5.17 & 4.91 & 4.99 & 0.93 \\
\hline \multicolumn{13}{|c|}{ Parameters for rumen } \\
\hline$\overline{\mathrm{pH}}$ & 6.64 & 6.54 & 6.54 & 6.50 & 6.53 & 6.56 & 6.60 & 6.53 & 6.53 & 6.64 & 6.60 & 0.01 \\
\hline NH3 & $12.87^{\mathrm{c}}$ & $8.81^{\mathrm{e}}$ & $7.88^{\mathrm{e}}$ & $9.22^{\mathrm{e}}$ & $10.37^{\mathrm{d}}$ & $11.99^{c}$ & $17.95^{\mathrm{b}}$ & $23.32^{\mathrm{a}}$ & $16.10^{\mathrm{b}}$ & $10.87^{\mathrm{d}}$ & $11.46^{\mathrm{c}}$ & 0.69 \\
\hline TVFA's & $7.09^{\mathrm{a}}$ & $6.89^{b}$ & $6.80^{\mathrm{b}}$ & $6.16^{\mathrm{c}}$ & $6.94^{\mathrm{b}}$ & $6.83^{\mathrm{b}}$ & $7.11^{\mathrm{a}}$ & $7.89^{\mathrm{a}}$ & $7.23^{\mathrm{a}}$ & $6.34^{c}$ & $6.39^{c}$ & 0.15 \\
\hline MP & $100.91^{\mathrm{e}}$ & $101.91^{\mathrm{e}}$ & $100.80^{\mathrm{e}}$ & $102.44^{\mathrm{d}}$ & $102.15^{\mathrm{d}}$ & 104.89 & $104.97^{\mathrm{c}}$ & $104.75^{\circ}$ & $109.37^{b}$ & $111.96^{\mathrm{b}}$ & $131.28^{\mathrm{a}}$ & 3.33 \\
\hline EMP & $24.16^{c}$ & $24.65^{c}$ & $24.13^{\mathrm{c}}$ & $24.94^{\mathrm{c}}$ & $24.77^{\mathrm{c}}$ & $26.16^{\mathrm{bc}}$ & $26.26^{\mathrm{bc}}$ & $26.10^{\mathrm{bc}}$ & $28.71^{\mathrm{b}}$ & $30.27^{\mathrm{ab}}$ & $33.14^{\mathrm{a}}$ & 0.86 \\
\hline SCFA & 3.19 & 3.14 & 3.19 & 3.11 & 3.13 & 2.98 & 2.98 & 2.99 & 2.75 & 2.61 & 2.65 & 0.04 \\
\hline ME & 3.75 & 3.73 & 3.75 & 3.73 & 3.73 & 3.69 & 3.69 & 3.69 & 3.62 & 3.58 & 3.65 & 0.01 \\
\hline
\end{tabular}

ME: metabolic energy (MJ/kg DM) - SCFA: short chin fatty acid $(\mu \mathrm{m})$ - EMP: efficiency of microbial protein - MP: microbial protein ( $\mathrm{mg} / 100 \mathrm{ml}$ rumen liqour)

levels of protein provide the nutrients required for the activity of the ruminum microflora. Higher GP, greater synthesis of microbial proteins and greater degradability were reflected in high activity. This can be extended due to the effect of adding nanocobalt to the fermentation. The addition of nanocobalt showed that ME increased (Maoetal et al 2013) and (Elghandour et al 2015). The high levels of microbial activity in rumen were reflected in the results of the growth factors produced for microbial growth and rumen activity and the capacity of nanocobalt to provide positive anaerobial conditions for microbial growth.

\subsubsection{Kinetics of gas production}

The gas output per gram of DM, OM, NDF, $\mathrm{ADF}$, hemicellulose and cellulose is shown in the Table 5 after 24 hours of incubation. The possible performance of gas was significantly influenced by cobalt nanoparticles being applied to the ration showing a substantial decrease for cobalt and nanocobalt in production of gas per gram of DM, OM, NDF, ADF and hemicellulose. On the other hand, the inclusion of cobalt nanoparticles in rations has led to a numerical rise in the production of gas per gram of cellulose. The fermentation rate $(\mathrm{P}<$ $0.05)$ between differential agents was adjusted 
within 24 hours after 24 hours with 100 percent cobalt addition and 25,50 percent nanocobalt in comparison with 0 percent additive. The output level of cobalt (100 per cent) and nanocobalt relative to the other additional phases was high ( 25 percent). The values for dry and organic matter were higher than for any addition of nanocobalt levels after 24 hours of incubation gas processing, $0 \%$ without additive and 100 percent cobalt. In comparison with any addition, the production of nanocobalt gas cellulose also has high values in any additions (1883.58) for $25 \%$ of nanocobalt hemicellulose production (1787.01). The results showed that the addition of nanocobalt to the ration improves cellulolytic bacteria's growth and may increase cellulose fermentation. In vitro-incubated cereal straws and feed groups of various types in buffered rume fluid, (Siegel 1991) suggested that the production was closely related to short chain fatty acid (CCFA) production by fermenting carbohydrates. Closely associated by (Bakker et al 1995) studies between SCFA and in-vitro gas production indicating that ruminants may provide energy. The degradation of the dry and organic matter after 24 hours of gas incubation was $50 \%$ better than that of the addition of nanocobalt, $25 \%$ of the same amount. The statistics showed that nanocobalt gas percentage was $25 \%$ hemicellulose, while cellulose nanocobalt was extremely degradable in $25 \%$ and $50 \%$, cobalt addition was high at all levels (25, 50, 75 and 125\%) compared with control and noocobalt. The figures showed that nanocobalt gas was the best performing degradability of all nanocobalt amounts. The results showed that adding cobalt and nanocobalt to the ration would increase the fermentation of cellulose and degradation of standard experimental ration through the growth of cellulolytic bacteria. The higher output degree of gas and the $\mathrm{M}$ depletion rate. Oleifera reveals that, because of the high content of fermentable nutrients, rumen microbes should have used the feed better. Higher potential in gas production would make a major contribution to the energy supply by processing fatty acids in short chains (Remesy et al 1995). Digestibility was alleged to be related to in vitro gas production and to the strong positive association between gas production and digestibility for dry matter (Datt and Singh, 1995, Kaiser et al 2014), implying that in all agricultural waste in this experiment, trace minerals are extremely deficient. It means that mineral fortification in the form of salt lick or diet inclusion is needed for ruminant feed. (Lina et al 2009) proposed that a $24 \mathrm{~h}$ gas volume after incubation regarding gas volume and output characteristics of in-vitro gases should be indirectly associated with metabolisable energy in feedstuffs. The production of gas can be considered an indication of degradation of carbohydrates. In the In-vitro analysis (Lina et al 2009, Rajendran 2013), gas volume was a good predictor for the prediction of digestibility, the end product and the substratum microbial protein microbes. The production of gas is mainly due to the fermentation of acetate, propionate and butyrate carbohydrates (Sahoo 2014a), and the total emission of gas poses major changes to the fractions of carbon hydrates (Te-Hsing et al 2007) Protein fermentation gas output is relatively small compared to carbohydrate fermentation, although fat in gas production is insignificant (Sahoo 2014b). Mathematical explanations on the gas processing profile allow the evaluation of the data on substrates and media variations in soluble and slow-fermentable feed components and fermentability (Newman et al 2009). Although the production of gas is nutritionally unsustainable (Ingale \& Chaudhari 2013), it provides a useful basis for ME, OMD and SCFA forecasts (Yang and Sun 2006). The metabolizable energy computed from in vitro gas production and $\mathrm{CP}$ is positive for the fat content of traditional in vivo feeds and the metabolizable energy value (Kaiser et al 2014). The MDGs are very different from other farm waste. Usage in the multiple regression equation in vitro gas calculation and chemical composition (Mishra et al 2014, Hahn 1997). The in vivo prediction of OMD (Iravani et al 2014) has been highly successful. The group also used a correlative method to estimate the ME content in feed by estimating in vitro gas output and chemical constituents and found that 


\section{Using In Vitro Technique to Evaluation Adding Nano Cobalt to Some Roughages}

the ME forecast is more accurate only based on gas and chemical components (Lina et al 2009). In other research, there has also been an important relationship between in vitro gas and in vivo digestibility (Lina et al 2009, Rajendran et al 2013, Koch 1997). (Akinfémi et al 2009) have shown that the nutritional value of tropical agricultural waste and their capacity for digestibilities with the energy content that can be metabolized can also be measured using in vitro gas processing technologies. OMD, SCFA and ME estimates also provide great support for the chemical composition and digestibility in vitro.

\subsection{The second experiment: In vitro disap- pearance}

\subsubsection{Rice Straw}

Data in Table 6 showed that rice straw had disappeared in vitro. Data explained that at 24 hours, there were high significant values. Disappearance of in vitro DM and OM by adding 25 percent of nanocobalt quantity (35.17 percent and 50.84 percent) compared to control (25.92 percent and 32.28 percent) and adding 50 percent of nanocobalt (24.20 percent and 31.89 percent), while the lowest value was found to be 50 percent of nanocobalt. It was observed that the values of in vitro DM and OM were missing after 48 hours. 25 percent with the addition of nanocobalt amount, whose values were 44.76 percent and 56.66 percent, respectively, increased significantly, whereas it decreased with control and 50 percent with the addition of nanocobalt. The increase in the disappearance of In vitro DM and OM may be attributed to the increase in the secretion of activity bacteria enzymes and the rapid use of rice straw's fermentable CF, DM and OM. The data showed a major impact $(\mathrm{P}<0.05)$ of the addition of nanocobalt in the improvement of the disappearance from In vitro DM and OM at 24 and 48 hours. In comparison with other treatments, particularly rice straw, it was used for straw by 25 percent. It was confirmed to have vanished at 48 hours the in vitro NDF, $\mathrm{ADF}$ and hemicellulose and cellulosic values. With the addition of nanocobalt standard, 25 percent increased dramatically, with values of 52.07 percent, 35.98 percent, 64.46 percent and 37.22 percent respectively, while it decreased with control and 50 percent with the addition of nanocobalt. PERCENT Increased disappearance of in vitro NDF, ADF, hemicellulose and cellulose might be because of a rise bacterial enzyme activity secretion and rapid use of CF, NDF, ADF, hemicellulose and cellulose fermentable rice straw. The addition of nanocobalt can increase ruminal microorganism growth by 25 percent, increasing the degradability of DM, cellulose and hemicellulose. The present findings agree with (Abd ElGalil 2000) who noted that bagasse's enzymatic treatment (cellulase enzymes) improved its dry matter and organic matter disappearance in vitro. Cellulase enzymes that break down special cellulasic or lignocellulosic bands in cell wall plants were reported by (Abd El-Galil 2006). (Colombatto et al 2003) reported that a combination of pre- and post-incubation impacts improved the fermentation of cellulose and xylan by fibrolytic enzymes. The attachment of ruminal microscopic organisms can increase and/or enhance access to the wall matrix and thus speed up the digestion rate (Nsereko et al 2000). CF digestibility increases more with the addition of a certain level of enzyme mixture $(2 \mathrm{~g} / \mathrm{kg}$ feed), than with lower or higher levels (Yang et al 1999; Beauchemin et al 2000). By producing a complex extracellular enzyme, Clostridium cellulovorans degrades native substrates effectively (Roger et al 2005). (Gado and Abd El-Galil 2009) found that the highest active strains on In vitro dry matter of bagasse in sheep were all strains isolated from sheep's rumen, while Acetobacter xylinum and Thermonospora fusca were the highest active strains on bagasse disappearance in In vitro DM. 
Table 5. Degradability after 24 hours of OM, DM, ADF, NDF, Hemicellulose and Cellulose (g /kg DM)

\begin{tabular}{|c|c|c|c|c|c|c|c|c|c|c|c|c|}
\hline Items & control & \multicolumn{6}{|l|}{ Normal } & \multicolumn{3}{|l|}{ Nano. } & \multicolumn{2}{|l|}{ SE } \\
\hline Level of cobal & & 25 & 50 & 75 & 100 & 125 & 25 & 50 & 75 & 100 & 125 & \pm \\
\hline Degradability & & & & & & & & & & & & \\
\hline GPdDM24 & $205.46^{\mathrm{a}}$ & $187.01^{\mathrm{d}}$ & $192.77^{b}$ & $188.12^{\mathrm{d}}$ & $189.52^{\mathrm{d}}$ & $187.01^{\mathrm{d}}$ & $192.12^{\mathrm{c}}$ & $185.47^{\mathrm{de}}$ & $172.78^{\mathrm{e}}$ & $183.11^{\mathrm{de}}$ & $168.27^{\mathrm{f}}$ & 2.10 \\
\hline GPdOM24 & $379.82^{\mathrm{a}}$ & $377.38^{\mathrm{b}}$ & $379.98^{\mathrm{a}}$ & $375.93^{\mathrm{bc}}$ & $376.76^{\mathrm{b}}$ & $369.80^{c}$ & $369.32^{\mathrm{c}}$ & $370.13^{c}$ & $357.04^{\mathrm{d}}$ & $349.22^{\mathrm{e}}$ & $334.83^{\mathrm{f}}$ & 4.30 \\
\hline GPdNDF24 & $1025.06^{\circ}$ & $753.86^{\mathrm{e}}$ & $810.95^{\mathrm{c}}$ & $830.81^{\mathrm{d}}$ & $788.83^{\mathrm{de}}$ & $873.49^{\mathrm{c}}$ & $973.50^{\mathrm{b}}$ & $859.89^{\mathrm{c}}$ & $793.30^{\mathrm{de}}$ & $715.69 \mathrm{e}^{\mathrm{f}}$ & $662.29^{f}$ & 19.11 \\
\hline GPdADF24 & $2434.50^{\circ}$ & $1426.18^{c}$ & $1603.56 \mathrm{~d}$ & $\mathrm{l}^{\mathrm{e}} 1716.49^{\mathrm{c}}$ & $1671.58^{d}$ & 1852.64 & 2037.85 & $1746.22^{\circ}$ & $1764.47^{d}$ & $1183.25^{t}$ & 1139.39 & 62.42 \\
\hline GPdhemi24 & 1873.79 & 1628.56 & 1644.55 & 1628.98 & 1495.61 & 1700.77 & 1883.58 & 1709.63 & 1450.67 & 1841.67 & 1194.78 & 75.18 \\
\hline GPdcell24 & 1391.15 & 2344.71 & 2299.35 & 2420.37 & 2523.75 & 2411.18 & 1787.01 & 1774.41 & 1577.83 & 1441.83 & 1033.48 & 131.42 \\
\hline
\end{tabular}

Table 6. Invitro disappearance of Rice straw

\begin{tabular}{|l|c|c|c|c|c|c|c|}
\hline \multicolumn{1}{|c|}{ Item } & \multicolumn{2}{|c|}{$\mathbf{2 4 h r s}$} & \multicolumn{3}{c|}{$\mathbf{4 8 h r s}$} & SE \\
\hline Level of cobalt & $\begin{array}{c}\text { Control } \\
(\mathbf{0} \%)\end{array}$ & $\mathbf{2 5 \%}$ & $\mathbf{5 0 \%}$ & Control & $\mathbf{2 5 \%}$ & $\mathbf{5 0 \%}$ & \pm \\
\hline DMD & $25.92^{\mathrm{b}}$ & $35.17^{\mathrm{a}}$ & $24.20^{\mathrm{b}}$ & $39.57^{\mathrm{b}}$ & $44.76^{\mathrm{a}}$ & 31.35 & 0.81 \\
\hline OMD & $32.28^{\mathrm{b}}$ & $50.84^{\mathrm{a}}$ & $31.89^{\mathrm{b}}$ & $47.39^{\mathrm{b}}$ & $56.66^{\mathrm{a}}$ & $34.12^{\mathrm{c}}$ & 0.76 \\
\hline NDFD & - & - & - & $43.43^{\mathrm{b}}$ & $52.07^{\mathrm{a}}$ & $40.07^{\mathrm{b}}$ & 0.90 \\
\hline ADFD & - & - & - & $32.15^{\mathrm{b}}$ & $35.98^{\mathrm{a}}$ & $30.70^{\mathrm{b}}$ & 0.66 \\
\hline Hemicell D & - & - & - & $40.38^{\mathrm{c}}$ & $64.46^{\mathrm{a}}$ & $49.60^{\mathrm{b}}$ & 0.97 \\
\hline Cell D & - & - & - & $26.42^{\mathrm{b}}$ & $37.22^{\mathrm{a}}$ & $20.15^{\mathrm{b}}$ & 0.65 \\
\hline
\end{tabular}

\subsubsection{Wheat Straw}

Data in Table 7 showed the disappearance of wheat straw in in vitro. Data explained that at 24 hours, there were high significant values. In vitro DM and OM disappearance in the addition of 25 percent nanocobalt level (29.26 percent and 37.59 percent) compared to control (21.19 percent and 26.63 percent) and the addition of 50 percent nanocobalt $(22.80$ percent and 23.09 percent), while the lowest value was found for the addition of 50 percent nanocobalt. It was observed that the values of In vitro DM and OM were missing after 48 hours. Significant increase with the addition of 50 percent nanocobalt level, whose values were 44.53 percent and 59.16 percent, respectively, while it decreased with control and 25 percent nanocobalt added. Increased disappearance of in vitro $\mathrm{DM}$ and $\mathrm{OM}$ may be due to increased secretion of activity enzymes of bacteria and rapid use of fermentable wheat straw CF, DM and OM. Data suggested that the addition of nanocobalt $(\mathrm{P}<0.05)$ had a major impact on the change at 24 hours of in vitro DM and OM, wheat straw had $25 \%$ added nanocobalt, while at 48 hours the wheat straw had 50 percent added DM, and OM vanished, compared with other treatment straws. The values for in vitro ADF, Hemicellulose and Cellulose were observed to disappear at $48 \mathrm{hrs}$. With the addition of nanocobalt level 25 percent, which values were 43.21 percent, 58.16 percent and 62.57 percent respectively, decreased significantly with control and the addition of nanocobalt 50 percent, but NDF disappearance increased significantly at $48 \mathrm{hrs}$ with the addition of nanocobalt level 50 percent was 62.23 percent, while it decreased with control and the addition of nanocobalt 25 percent. Increased disappearance of in vitro ADF, NDF, cellulose and hemicellulose may be caused by increasing secretion of the bacterial enzyme and fast use of fermentable rice straw $\mathrm{CF}$, NDF, ADF, hemicellulosis, and cellulose. The addition of nanocobalt can increase ruminal microorganism growth by 25 percent, increasing the degradability of DM, cellulose and hemicellulose. 

to Some Roughages

Table 7. Invitro disappearance of Wheat straw

\begin{tabular}{|l|c|c|c|c|c|c|c|}
\hline \multicolumn{1}{|c|}{ Item } & \multicolumn{3}{|c|}{$\mathbf{2 4 h r s}$} & \multicolumn{3}{c|}{$\mathbf{4 8 h r s}$} & SE \\
\hline Level of cobalt & Control (0 \%) & $\mathbf{2 5 \%}$ & $\mathbf{5 0 \%}$ & Control $^{25 \%}$ & $\mathbf{5 0 \%}^{\mathbf{2 5 \%}}$ & $\mathbf{\pm}$ \\
\hline DMD & $21.19^{\mathrm{b}}$ & $29.26^{\mathrm{a}}$ & $22.80^{\mathrm{b}}$ & $30.46^{\mathrm{b}}$ & $41.84^{\mathrm{a}}$ & $44.53^{\mathrm{a}}$ & 0.77 \\
\hline OMD & $26.63^{\mathrm{b}}$ & $37.59^{\mathrm{a}}$ & $23.09^{\mathrm{b}}$ & $36.16^{\mathrm{c}}$ & $42.87^{\mathrm{b}}$ & $59.16^{\mathrm{a}}$ & 1.01 \\
\hline NDFD & - & - & - & 34.77 & 31.86 & $62.23^{\mathrm{a}}$ & 0.93 \\
\hline ADFD & - & - & - & $33.71^{\mathrm{b}}$ & $43.21^{\mathrm{a}}$ & $35.64^{\mathrm{b}}$ & 0.85 \\
\hline Hemicell D & - & - & - & $33.81^{\mathrm{c}}$ & $58.16^{\mathrm{a}}$ & $43.31^{\mathrm{b}}$ & 0.82 \\
\hline Cell D & - & - & - & $43.43^{\mathrm{c}}$ & $62.57^{\mathrm{a}}$ & $51.56^{\mathrm{b}}$ & 1.12 \\
\hline
\end{tabular}

\subsubsection{Bagasse}

The data in Table 8 showed that there was a clear disappearance of in vitro bagasse. Data clarified that there were high significant values at $24 \mathrm{hrs}$. In the addition of nanocobalt level, 25 percent (36.82 percent) of in vitro DM, but 50 percent (48.40 percent) of OM disappearance in the addition of nanocobalt level compared to control (27.63 percent and 29.04 percent). Increased disappearance of Invitro DM and OM may be due to increased secretion of bacterial activity enzymes and rapid utilization of bagasse fermentable CF. The data showed the important $(\mathrm{P}<0.05)$ effect on in vitro $\mathrm{DM}$ in 24 compared with other treatments with addition of nanocobalt compared with bagasse, which includes $25 \%$ of the added nanocobalt in straw. It was noted that with the addition of 50 percent of nanocobalt, the disappearance of Invitro NDF, ADF and cellulose at $48 \mathrm{hrs}$ increased significantly, whereas it decreased with control and 25 percent with the addition of nanocobalt. Increased disappearance of in vitro Hemicellulose may be due to increased secretion of bacterial activity enzymes and rapid use of $\mathrm{CF}, \mathrm{NDF}, \mathrm{ADF}$, and cellulose fermentable bagasse. The addition of nanocobalt can increase the growth of ruminal microorganisms by 50 percent, thereby increasing DM, cellulose and hemicellulose degradability.

\subsubsection{Bean Straw}

The data in Table 9 showed that bean straw disappearance in in vitro was observed. Data explained that at 24 hours, there were high significant values. Compared to control (32.01 percent and 37.32 percent) and adding nanocobalt $50 \%$ (26.51 percent and 29.34 percent), 25 percent ( 35.93 percent and 45.46 percent) of in vitro $\mathrm{DM}$ and $\mathrm{OM}$ disappearance in adding nanocobalt level compared to control (32.01 percent and 37.32 percent) and adding nanocobalt 50 percent (26.51 percent and 29.34 percent), although the highest values for adding nanocobalt 50 percent were found. It was found that the values of in vitro DM, NDF, ADF, hemicellulose and cellulose disappeared at 48 hours. With the addition of nanocobalt standard, 25 percent increased significantly, with values of $54.77,45.53,36.38,53.56$ and 63.44 percent respectively, whereas it decreased with control and 50 percent with the addition of nanocobalt, except that the value of OM disappearance was high (60.21 percent) relative to other rations. Increased disappearance of in vitro DM may be attributed to increased secretion of activity bacteria enzymes and rapid use of bean straw's fermentable CF, $\mathrm{DM}$ and OM. Data revealed the significant impact on in vitro DM and OM's disappearance at 24 and 48 hours by addition of nanocobalt $(\mathrm{P}<0.05)$. In particular, bean straw contained a $25 \%$ addition of nanocobalt to straw relative to other treatments. The values of in vitro NDF, ADF, Hemicellulose and Cellulose were observed to disappear after 48 hours. It increased significantly with the addition of 25 percent nanocobalt quantity, although it decreased with control and 50 percent added nanocobalt. In vitro $\mathrm{NDF}$, ADF, Hemicellulose and Cellulose disappearance can increase 
as a result of increased bacterial enzyme activity and fast use of fermentable rice strokes such as CF, NDF, NDF, ADF, Hemicelluloses and cellulose. The addition of nanocobalt will increase ruminal microorganism growth by 25 percent, increasing the degradability of DM, cellulose and hemicellulose.

\subsubsection{Peanut Straw}

Data in Table 10 showed the disappearance of peanut straw in in vitro. Data explained that there were high significant values at $24 \mathrm{hrs}$. in vitro $\mathrm{DM}$ and $\mathrm{OM}$ disappearance compared to control (25.92 percent and 43.07 percent) and adding nanocobalt 50 percent (26.71 percent and 41.72 percent) in adding nanocobalt level 25 percent (34.76 percent and 51.30 percent), while the lowest value was found for adding nanocobalt 50 percent. It was observed that the values of in vitro DM and OM were missing after 48 hours. 25 percent, whose values were 42.49 percent and 56.71 percent, respectively, increased significantly with the addition of nanocobalt quantity, whereas it decreased with control and 50 percent with nanocobalt addition. Increased disappearance of Invitro DM and $\mathrm{OM}$ can be due to increased secretion of bacterial enzyme activity and rapid use of fermentable CF, DM and OM of Peanut straw. The data showed that the addition of nanocobalt had a substantial effect $(\mathrm{P}<0.05)$ on the improvement of in vitro DM and OM disappearance at 24 and $48 \mathrm{hrs}$. Only one treatment, especially peanut straw, contained 25 percent nanocobalt added to peanut straw compared to other treatments. The values of in vitro NDF, ADF, Hemicellulose and Cellulose were observed to disappear after 48 hours. With the addition of nanocobalt levels, whose values were 43.65 percent, 26.33 percent, 61.58 percent and 47.97 percent respectively, 25 percent in- creased significantly with the addition of nanocobalt levels, but with regulation it decreased and with the addition of nanocobalt it decreased 50 percent. In-vitro NDF, ADF, Hemicellulose and Cellulose have been gradually lost due to increased secretions of bacterial enzymes and quick use of fermentable peanut straw CF, NDF, ADF, Hemicellulose and Cellulose. The addition of nanocobalt will increase ruminal microorganism growth by 25 percent, increasing the degradability of DM, cellulose and hemicellulose. In contrast, (Partha Sarathi Swain et al 2015) stated that mineral nanoparticles have significant potential, even at very low doses than traditional organic and inorganic sources, as mineral feed supplements in livestock. However, systematic and comprehensive researching the toxic effects, if any, after animal feeding should be undertaken over a long time. Moreover, a large number of animals should be fed these synthesized mineral nanoparticles to standardize positive and adverse effects before being routinely introduced into the ration. (Etab and El-Bordeny 2018) results showed that added nanocobalt impacts the growth of cellulolytic bacteria and increases cellulose, ammonia, total volatile fatty acids, metabolisable energy, and cell wall constituent degradability. Further research would thus be required to see the effects of nanomineral supplements on in vitro gas production and in vitro degradability. DM fermentation is a very important factor in the nutrients used by ruminants, both in rate and in degree. Because of the advantages of gas production with easy use and the ability to produce a great many samples in a short time, substantial results would be expected (Valentin et al 1999). Several students have researched in vitro gas processing techniques for fermentation kinetics (Cone et al 1998, 1999 and 2002). 

to Some Roughages

Table 8. Invitro disappearance of Bagasse

\begin{tabular}{|l|c|c|c|c|c|c|c|}
\hline \multicolumn{1}{|c|}{ Item } & \multicolumn{3}{|c|}{ 24hrs } & \multicolumn{3}{c|}{$\mathbf{4 8 h r s}$} & SE \\
\hline \multicolumn{1}{|c|}{ Level of cobalt } & Control (0 \%) & $\mathbf{2 5 \%}$ & $\mathbf{5 0 \%}$ & Control $^{\text {25\% }}$ & $\mathbf{2 5 \%}$ & $\mathbf{5 0 \%}$ \\
\hline DMD & $27.63^{\mathrm{b}}$ & $36.82^{\mathrm{a}}$ & $34.12^{\mathrm{a}}$ & $33.01^{\mathrm{b}}$ & $37.08^{\mathrm{a}}$ & $40.82^{\mathrm{a}}$ & 0.65 \\
\hline OMD & $29.04^{\mathrm{b}}$ & $43.09^{\mathrm{a}}$ & $48.40^{\mathrm{a}}$ & $35.61^{\mathrm{b}}$ & $44.57^{\mathrm{a}}$ & $51.58^{\mathrm{a}}$ & 0.76 \\
\hline NDFD & - & - & - & $56.98^{\mathrm{b}}$ & $58.38^{\mathrm{a}}$ & $62.99^{\mathrm{a}}$ & 1.30 \\
\hline ADFD & - & - & - & $38.89^{\mathrm{b}}$ & $39.95^{\mathrm{b}}$ & $45.89^{\mathrm{a}}$ & 1.02 \\
\hline Hemicell D & - & - & - & $37.98^{\mathrm{c}}$ & $57.44^{\mathrm{a}}$ & $43.68^{\mathrm{b}}$ & 0.93 \\
\hline Cell D & - & - & - & $26.32^{\mathrm{b}}$ & $27.37^{\mathrm{b}}$ & $33.31^{\mathrm{a}}$ & 0.59 \\
\hline
\end{tabular}

Table 9. Invitro disappearance of Bean straw

\begin{tabular}{|l|c|c|c|c|c|c|c|}
\hline \multicolumn{1}{|c|}{ Item } & \multicolumn{2}{|c|}{$\mathbf{4 h r s}$} & \multicolumn{3}{c|}{$\mathbf{4 8 h r s}$} & SE \\
\hline Level of cobalt & $\begin{array}{c}\text { Control } \\
(\mathbf{0} \%)\end{array}$ & $\mathbf{2 5 \%}$ & $\mathbf{5 0 \%}$ & Control & $\mathbf{2 5 \%}$ & $\mathbf{5 0 \%}$ & \pm \\
\hline DMD & $32.01^{\mathrm{a}}$ & $35.93^{\mathrm{a}}$ & $26.51^{\mathrm{b}}$ & $44.39^{\mathrm{b}}$ & $54.77^{\mathrm{a}}$ & $45.41^{\mathrm{b}}$ & 0.73 \\
\hline OMD & $37.32^{\mathrm{b}}$ & $45.46^{\mathrm{a}}$ & $29.34^{\mathrm{c}}$ & $44.98^{\mathrm{b}}$ & $56.32^{\mathrm{a}}$ & $60.21^{\mathrm{a}}$ & 0.92 \\
\hline NDFD & - & - & - & $40.83^{\mathrm{b}}$ & $45.53^{\mathrm{a}}$ & $39.38^{\mathrm{b}}$ & 0.84 \\
\hline ADFD & - & - & - & $21.13^{\mathrm{b}}$ & $36.38^{\mathrm{a}}$ & $33.65^{\mathrm{a}}$ & 0.75 \\
\hline Hemicell D & - & - & - & $42.10^{\mathrm{b}}$ & $53.56^{\mathrm{a}}$ & $43.61^{\mathrm{b}}$ & 1.01 \\
\hline Cell D & - & - & - & $46.58^{\mathrm{c}}$ & $63.44^{\mathrm{a}}$ & $52.28^{\mathrm{b}}$ & 1.20 \\
\hline
\end{tabular}

Table 10. Invitro disappearance of Peanut straw

\begin{tabular}{|l|c|c|c|c|c|c|c|}
\hline Item & \multicolumn{3}{|c|}{$\mathbf{2 4 h r s}$} & \multicolumn{3}{|c|}{$\mathbf{4 8 h r s}$} & SE \\
\hline Level of cobalt & $\begin{array}{c}\text { Control } \\
(\mathbf{0} \%)\end{array}$ & $\mathbf{2 5 \%}$ & $\mathbf{5 0 \%}$ & Control & $\mathbf{2 5 \%}$ & $\mathbf{5 0 \%}$ & \pm \\
\hline DMD & $25.92^{\mathrm{b}}$ & $34.76^{\mathrm{a}}$ & $26.71^{\mathrm{b}}$ & $38.18^{\mathrm{b}}$ & $42.49^{\mathrm{a}}$ & $36.17^{\mathrm{b}}$ & 0.71 \\
\hline OMD & $43.07^{\mathrm{b}}$ & $51.30^{\mathrm{a}}$ & $41.72^{\mathrm{b}}$ & $51.34^{\mathrm{b}}$ & $56.71^{\mathrm{a}}$ & $46.70^{\mathrm{b}}$ & 0.80 \\
\hline NDFD & - & - & - & $39.37^{\mathrm{b}}$ & $43.65^{\mathrm{a}}$ & $31.90^{\mathrm{b}}$ & 0.59 \\
\hline ADFD & - & - & - & $26.10^{\mathrm{a}}$ & $26.33^{\mathrm{a}}$ & $18.71^{\mathrm{b}}$ & 0.48 \\
\hline Hemicell D & - & - & - & $36.39^{\mathrm{c}}$ & $61.58^{\mathrm{a}}$ & $51.59^{\mathrm{b}}$ & 0.79 \\
\hline Cell D & - & - & - & $33.08^{\mathrm{b}}$ & $47.97^{\mathrm{a}}$ & $30.86^{\mathrm{b}}$ & 0.88 \\
\hline
\end{tabular}

DMD: Dry Matter Digestibility, OMD: Organic Matter Digestibility, NDFD: Neutral detergent fiber Digestibility, ADFD: Acid-Detergent fiber Digestibility

\section{Conclusion}

It concluded that impact of adding nanocobalt on the degradability of all roughages as DM, OM, NDF, ADF, Cellulose and Hemicellulose in this experiment. Furthermore, the addition of nano-cobalt was found to have a substantial effect (24 and 48 hours of in vitro DM and $\mathrm{OM}$ disappearance in rice straw, wheat Straw, bean straw and peanut paw), while the increase in disappearance at in vitro DM and
OM was significantly impacted by bagasse in 24 and 48 hours. Add 50\% nanocobalt to it. An increased disappearance of in vitro NDF, ADF, Hemicellulose and Cellulose is attributed to increased secretion of bacterial enzymes and rapid use of some fermentable roughages such as $\mathrm{CF}, \mathrm{NDF}, \mathrm{ADF}$, Hemicellulose and Cellulose. The addition of nanocobalt will increase growth of ruminal microorganisms by 25 per cent, improving DM, cellulose and hemicellulose degradability. Therefore, it 
must be further examined the effects of nanomineral supplementation on improving in vitro degradation.

\section{References}

Akinfemi A, Adesanya AO, Aya VE (2009) Use of an In vitro gas production technique to evaluate some Nigerian feedstuffs. Amer-Eurasian J Scientif Res, 4, 240-245.

AOAC (1997) Association of Official Analytical Chemists, Official Methods of Analysis, $16^{\text {th }}$ edition, Maryland. USA.

Abd El-Galil ERI (2000) Nutritional factors affecting the performance of small ruminants. M.Sc. Thesis, Faculty of Agriculture. AinShams University. pp 55-90.

Abd El-Galil ERI (2006) Effect of biological treatments on silage and feeding value of roughages in ruminants. Ph.D. Thesis, Faculty of Agriculture. Ain-Shams University. pp 4347.

Beauchemin KA, Rode LM, Maekawa M, Morgavi DP, Kampen R (2000) Evaluation of a non starch polysaccharides feed enzyme in dairy cow ration. J Dairy Sci, 83, 543.

Bakker H, Zhou GF, Yang H (1995) Mechanically driven disorder and phase transformations in alloys. Prog Mater Sci, 39, 159241.

Barnett AJ, Reid RC (1956) Studies on the production of volatile fatty acids from the grass by rumen liquor in an artificial rumen VFA production from grass. J Agri Sci, 48, 131-161.

Blummel M, Orskov ER (1993) Comparison of In vitro gas production and nylon bag degradability of roughages in predicting of food intake in cattle. Anim Feed Sci Technol, 40, 109119.
Blummel M, Steingas H, Becker K (1997) The relationship between in vitro gas production, in vitro microbial biomass yield and $\mathrm{N}$ incorporation and its implications for the prediction of voluntary feed intake of roughages. British $J$ Nutr, 77, 911-921.

Bunglavan SJ, Garg AK, Dass RS, Shrivastava $S$ (2014) Use of nanoparticles as feed additives to improve digestion and absorption in livestock. Livestock Research International 2, 3647.

Colombatto D, Moulda FL, Bhat MK, Owen E (2007) Influence of exogenous fibrolytic enzyme level and incubation $\mathrm{pH}$ on the in vitro ruminal fermentation of alfalfa stems. Anim Feed Sci Technol, 137, 150-162.

Cone JW, Van Gelder AH, Valk H (1998) Prediction of nylon bag degradation characteristics of grass samples with the gas production technique. J Sci Food Agric, 77, 421-426.

Cone JW, Van Gelder AH, Bachmann H, Hindle VA (2002) Comparison of organic matter degradation in several feedstuffs in the rumen as determined with the nylon bag and gas production techniques. Anim Feed Sci Technol, 96, 55-57.

Cone JW, Van Gelder AH, Soliman IA, De Visser H, Van Vuuren AM (1999) Different techniques to study rumen fermentation characteristics of maturing grass and grass silage. $J$ Dairy Sci, 82, 957-966.

Datt C, Singh GP (1995) Effect of protein supplementation on in vitro digestibility and gas production of wheat straw. Indian J Dairy Sci, 48, 357-361.

Devendra C (1997) Crop residues for feeding animals in Asia: Technology development and adoption in crop/livestock systems. In: Crop Residuals in Sustainable Mixed Crop/livestock Farming System (Ed. C. Renard). CAB International; Wallingford, UK. pp. 241-267. 


\section{Using In Vitro Technique to Evaluation Adding Nano Cobalt to Some Roughages}

Duncan DB (1955) Multiple range and multiple F-test. Biometrics, 11, 1-42.

Elghandour MMY, Salem AZM, Martínez Castañeda JS, Camacho LM, Kholif AE, Vázquez Chagoyán JC (2015) Direct-fed microbes: a tool for improving the utilization of low quality roughages in ruminants. $J$ Integr Agr, 14, 526-533.

Elghandour MMY, Vázquez Chagoyán JC, Salem AZM, Kholif AE, Martínez Castañeda JS, Camacho LM, Cerrillo-Soto MA (2014) Effects of Saccharomyces cerevisiae at direct addition or pre-incubation on In vitro gas production kinetics and degradability of four fibrous feeds. Ital J Anim Sci 13, 295-301.

Abd El-Galil ERI, El-Bordeny NEY (2018) Evaluation of nanocobalt particles addition in ruminant rations by in vitro gas production. Egyptian J Nutrition and Feeds, 21, 91-102.

Gado HM, Abd El-Galil ERI (2009) Evaluation differences of some ruminal bacteria by In vitro dry matter, cellulose and hemicellulose disappearance rate and extent of bagasse. Egyptian J Nutrition and Feeds 12, 359-372.

Gall LS, Smith SE, Becker DE, Stark CN, Loosli JK (1949) Rumen bacteria in cobalt-deficient sheep. Science 109, 468-469.

Getachew G, Makkar HPS, Becker K (2002) Tropical browses: Contents of phenolics compounds, In vitro gas production and stoichiometric relationship between short chain fatty acid and In vitro gas production. J Agric Sci, 139, 341-352.

Hahn H (1997) Unique features and properties of nanostructured materials. Nanostruct Mater, 9, 3-12.

Hansen HH, Ebied HM, El-Bordeny N (2016) In vitro evaluation of Moringa seeds cake as a feedstuff for dairy animal (under publication).
Hristov AN, Oh J, Firkins JL, Dijkstra J, Kebreab E, Waghorn G, Makkar HP, Adesogan AT, Yang W, Lee C (2013) Special topics: mitigation of methane and nitrous oxide emissions from animal operations: I. A review of enteric methane mitigation options. J Anim Sci, 91, 5045-5069.

Ingale AG, Chaudhari AN (2013) Biogenic synthesis of nanoparticles and potential applications: An eco-friendly approach. J Nanomed Nanotechol, 4, 165.

Iravani S, Korbekandi H, Mirmohammadi SV, Zolfaghari B (2014) Synthesis of silver nanoparticles: Chemical, physical and biological methods. Res Pharm Sci, 9, 385-406.

Kaiser DL, Standridge S, Friedersdorf L, Geraci CL, Kronz F, Meador MA, Stepp DM (2014) National Nanotechnology Initiative Strategic Plan by National Science and Technology Council Committee on Technology. Subcommitte on Nanoscale Science, Engineering and Technology, p 30.

Khazaal K, Markantonatos X, Nastis A, Orskov ER (1993) Changes with maturity in fiber composition and levels of extractable polyphenols in Greek browse: effect on vitro gas production and in sacco dry matter degradation. $J$ Sci Food Agric 63, 237-244.

Kholif AE, Khattab HM, El-Shewy AA, Salem AZM, Kholif AM, El-Sayed MM, Gado HM, Mariezcurrena MD (2014) Nutrient digestibility, ruminal fermentation activities, serum parameters and milk production and composition of lactating goats fed diets containing rice straw treated with with Pleurotus ostreatus. Asian-Australas J Anim Sci, 27, 357-364.

Koch CC (1997) Synthesis of nanostructured materials by mechanical milling: Problems and opportunities. Nanostruct Mater, 9, 13-22. 
Koutzarova T, Kolev S, Ghelev C, Paneva D, Nedkov I (2006) Microstructural Study and Size Control of Iron Oxide Nanoparticles Produced by Microemulsion Technique. Phys Stat Sol, 3, 1302-1307.

Koutzarova T, Kolev S, Ghelev C, Paneva D, Nedkov I (2006) Microstructural Study and Size Control Of Iron Oxide Nanoparticles Produced by Microemulsion Technique. Phys Stat Sol, 3, 1302-1307.

Krishnamoorthy H, Steingass H, Menke KH (1991) Preliminary observations on the relationships between gas production and microbial protein synthesis in vitro. Arch Tierernahr, 41, 521-526.

Krishnamoorthy U, Singh KC, Kailas MM (2005) Evaluation of roughages for rumen microbial biomass synthesis. Indian Vet $J, 82$, 453-454.

Lina T, Jianyang J, Fenghua Z, Huiying R, Wenli L (2009) Effect of nano-zinc oxide on the production and dressing performance of broiler. Chinese Agricultural Science Bulletin, 2, 003 .

Manigandan R, Giribabu K, Suresh R, Vijayalakshmi L, Stephen A, Narayanan V (2013) Cobalt Oxide Nanoparticles: Characterization and its Electrocatalytic Activity towards Nitrobenzene. Chem Sci Trans, 2, 47-50.

Mao HL, Wang JK, Liu JX, Yoon I (2013). Effects of Saccharomyces Cerevisiae fermentation product on In vitro fermentation and microbial communities of low-quality forages and mixed diets. J Anim Sci, 91, 3291-3298.

Menke HH, Steingass H (1988) Estimation of the energetic feed value obtained from chemical analysis and In vitro gas production using rumen fluid. Anim Res Dev, 28, 7-55.

Mishra A, Swain RK, Mishra SK, Panda N, Sethy K (2014). Growth performance and serum biochemical parameters as affected by nano zinc supplementation in layer chicks. Indian J Anim Nutr, 31, 384-388.
Newman MD, Stotland M, Ellis JI (2009) The safety of nanosized particles in titanium dioxide - and zinc-oxide based sunscreens. $J \mathrm{Am}$ Acad Dermatol, 61, 685-692.

NRC (1985) National Research Council, Nutrition requirements of goats. $6^{\text {th }}$ revised $\mathrm{Ed}$. National Academy Press. Washington. D.C., USA.

Nsereko VL, Morgavi DP, Rode LM, Beauchemin KA, McAllister TA (2000) Effects of fungal enzyme preparation on hydrolysis and subsequent degradation of alfalfa hay by mixed rumen microorganisms in vitro. Animal Feed Science and Technology, 88, 153170.

Orskov ER (1989) Recent advances in evaluation of roughages as feeds for ruminants. In: Farell D.J. (ed): Advances in animal nutrition. University of New England Printery, Armidale, pp 102-108.

Partha SS, Rajendran D, Rao SBN, Dominic G (2015) Preparation and effects of nano mineral particle feeding in livestock. A Review, Veterinary World 8, 888-891.

Rajendran D (2013) Application of nano minerals in animal production system. Res $J$ Biotechnol, 8, 1-3.

Rajendran D, Thulasi A, Jash S, Selvaraju S, Rao SBN (2013) Synthesis and application of nano mineralsin livestock industry. In: Sampath, KT; Ghosh, J; Bhatta, R, editors. Animal Nutrition and Reproductive Physiology (Recent Concepts). Satish Serial Publishing House, Delhi, pp 517-530.

Remesy C, Demigne C, Morand C (1995) Metabolism of short-chain fatty acids in the liver. In: Cummings, JH, Rombeau, JL, Sakata, T, (eds), Physiological and clinical aspects of short- chain fatty acids, (Cambridge University Press, Cambridge), pp 171-190.

Roger K, Hee-Yean C, Akihiko K, Masayuki I, Hideaki Y, Roy HD (2005) Degradation of corn fiber by Clostridium cellulovorans cellulases and hemicellulases and contribution of scaffolding protein. Appl Environ Microbiol, 71, 3504-3511. 


\section{Using In Vitro Technique to Evaluation Adding Nano Cobalt to Some Roughages}

Sahoo A, Swain RK, Mishra SK, Jena B (2014a) Serum biochemical indices of broiler birds fed on inorganic, organic and nano zinc supplemented diets. Int J Recent Sci Res, 5, 2078-2081.

Sahoo A, Swain RK, Mishra SK (2014b) Effect of inorganic, organic and nano zinc supplemented diets on bioavailability and immunity status of broilers. Int J Adv Res, 2, 828-837.

SAS (1998) Statistical analysis system. User's Guide Inst., Inc. Cary, NC, USA.

Scholljegerdes EJ, Hill WJ, Purvis HT, Voigt LA, Schauer CS (2010) Effects of Supplemental Cobalt on Nutrient Digestion and Nitrogen Balance in Lambs Fed Forage-based Diets. Sheep \& Goat Research Journal, 25, 7477.

Siegel RW (1991) Processing of Metals and Alloys. In: Cahn, RW (ed). Materials Science and Technology 15, 583.

Sutton AL, Elliot JM (1972) Effect of ratio of roughage to concentrate and level of feed intake on ovine ruminal vitamin B12 production. J Nutr 102, 1341-1346.

Szumacher-Strabel M, Potkanski A, Kowalczyk J, Cieslak A, Czauderna M, Gubala M, Jedroszkowiak P (2002) The influence of supplemental fat on rumen volatile fatty acid profile, ammonia and $\mathrm{pH}$ level in sheep fed a standard diet. Journal of Animal and Feed Sciences, 11, 577-587.

Te-Hsing W, Yi-Der T, Lie-Hang S (2007) The novel methods for preparing antibacterial fabric composites containing nano-material. Solid State Phenom, 124, 1241-1244.

Terry RA, Tilley JMA, Outen GE (1969) Effect of $\mathrm{pH}$ on cellulose digestion under in-vitro Conditions. J Sci F Agric, 20, 317.
Tiffany ME, Spears JW, Xi L, Valdez FR (2002) Effects of dietarycobalt source and oncentration on performance, vitamin B12 status, and ruminal and plasma metabolites in growing and finishing steers. J Anim Sci 80 (Suppl. 1), 183. (Abstr.)

Tiffany ME, Fellner V, Spears JW (2006) Influence of cobalt concentration on vitamin B12 production and fermentation of mixed ruminal microorganisms grown in continuous culture flow-through fermentors. J Anim Sci, 84, 635640.

Valentin SF, Williams PEV, Forbes JM, Sauvant D (1999) Comparison of the In vitro gas production technique and the nylon bag degradability technique to measure short and long term processes of degradation of maize silage in dairy cows. Anim Feed Sci Technol, 78, 81-99.

Van Soest PJ, Breston J (1979) Systems of Analysis for Evaluation Fibrous Feeds In: Standardization of Analytical Methodology for Feed, USA, p 49.

Van Soest PV, Robertson JB, Lewis BA (1991) Methods for dietary fiber, neutral detergent fiber and non starch polysaccharides in relation to animal nutrition. J Dairy Sci, 74, 3583-3597.

Yang ZP, Sun LP (2006) Effects of nanometre $\mathrm{ZnO}$ on growth performance of early weaned piglets. J Shanxi Agric Sci, 3, 024.

Yang WZ, Beauchemin KA, Rode LM (1999) Effects of an enzyme feed additive on extent of digestion and milk production of lactating dairy cows. J Dairy Sci, 82, 391-403. 